\title{
One of the rare reason of abdominal pain: abdominal wall endometriosis
}

\author{
Sefa Ergün' $(\mathbb{D}$, Kazım Koray Öner² \\ ${ }^{1}$ Department of General Surgery, Istanbul University-Cerrahpasa, Cerrahpasa Faculty of Medicine, Istanbul, Turkey \\ ${ }^{2}$ Clinic of General Surgery, Avcılar Murat Kölük Public Hospital, İstanbul, Turkey
}

\begin{abstract}
Objective: Endometriosis is defined as the presence of normal endometrial mucosa abnormally implanted in locations other than the uterine cavity. It is most commonly located in the pelvis but it is also rarely observed in the gastrointestinal tract, lung, liver, kidneys, central nervous system and abdominal wall. Abdominal wall endometriosis (AWE) commonly occurs following a caesarean section or pelvic surgery. The patients consult the physician mostly with complaints of cyclic abdominal pain and a palpable mass in the abdomen. The basic methods in diagnosing AWE are anamnesis and physical examination but ultrasound, computerized tomography, and sometimes magnetic resonance imaging of the abdomen are also used.

Material and Methods: In our study, we retrospectively analyzed 9 patients who underwent surgery at Avcılar State Hospital General Surgery Service between January 2015 and December 2018 with a preliminary diagnosis of AWE and confirmation through pathology results.

Results: Median age of the patients was $32 \pm 4.66$ and median body mass index (BMI) was $24.6 \pm 1.15$. Every patient except 1 had a history of cesarean section history. One patient was operated because of recurrence. Patients consulted the hospital with complaints of pain during menstruation and abdominal swelling. The start of the complaints was 4.1 years following C-section. Mostly ultrasound was used for imaging. For treatment, they all received en-bloc mass excision and their pathological diagnosis were compliant with endometriosis. Average surgery time was 40 minutes and average endometriosis lesion dimension was $3.4 \mathrm{~cm}$. It was observed that the lesion extended to the anterior abdominal fascia in 6 of the patients, and 2 patients underwent fascia repair with propylene mesh because of the excessive defect size. No postoperative complication occured in any patient and no recurrence is observed.

Conclusion: In patients with periodic abdominal pain and swelling on the abdominal wall, AWE could be suspected and early diagnosis can be realized by carefully taking medical history and following physical examination, and appropriate radiological examinations and necessary surgical intervention can be performed. The method of diagnosis and treatment is to remove the lesion through wide excision.
\end{abstract}

Keywords: Endometriosis, abdominal wall, abdominal pain

Cite this article as: Ergün S, Öner KK. One of the rare reasons of abdominal pain: abdominal wall endometriosis. Turk J Surg 2021; 37 (1): 68-72.

Corresponding Author

Sefa Ergün

E-mail: sefaergn@yahoo.com

Received: 12.08 .2020

Accepted: 27.01 .2021

Available Online Date: 22.03 .2021

o Copyright 2021 by Turkish Surgical Society Available online at www.turkjsurg.com

DOI: $10.47717 /$ turkjsurg.2021.4994

\section{INTRODUCTION}

Endometriosis is defined as the presence of normal endometrial mucosa abnormally implanted in locations other than the uterine cavity. Endometriosis was first described in 1860, and it affects $5 \%-10 \%$ of women population $(1,2)$. It is most commonly located in the pelvis but in $12 \%$ of the published cases, it is also rarely observed in the gastrointestinal tract, lung, liver, bladder, kidneys, umbilicus, extremities, central nervous system and abdominal wall $(1,3)$.

Abdominal wall endometriosis (AWE), which was first reported by Meyer in 1903, is rarely observed, but it occurs most frequently following a cesarean or pelvic surgery. The patients consult the physician mostly with complaints of cyclic abdominal pain and a palpable mass in the abdomen $(2,4,5)$. In the presence of the mass found, it can be mixed up with lipoma, abscess, hematoma, hernia, granuloma, desmoid tumor or sarcoma. The basic methods in diagnosing AWE are anamnesis and physical examination but ultrasound, computerized tomography, and sometimes magnetic resonance imaging of the abdomen are used in the differential diagnosis $(3,4)$.

Although there are many theories in AWE etiology, the most accepted one is the direct spread of the endometrium cells through iatrogenic ways and the formation of endometriosis in the surgical field. Cesarean increases AWE formation 27 times in the society, and in recent years, AWE observation rate has increased in parallel with the increase in the cesarean section rate $(1,3)$. 
In our study, it was aimed to examine the diagnosis, treatment and follow-up information of patients diagnosed with AWE pathology at the Avcllar State Hospital for 4 years, following the current literature.

\section{MATERIAL and METHODS}

In our study, we retrospectively analyzed 9 patients who underwent surgery at Avcılar State Hospital General Surgery Service between January 2015 and December 2018 with a preliminary diagnosis of AWE and confirmation through pathology results. Demographic information, medical history, complaints, cesarean history, diagnosis and treatment methods, length of hospital stay, pathology results of each patient were taken from their medical files, and their follow-up was recorded through patient controls and phone conversations.

All quantitative data were expressed as mean \pm standard deviation. The qualitative variables were defined by frequencies (\%). This study was approved by the Ethics Committee of Istanbul University-Cerrahpasa, Cerrahpasa Medical Faculty with approval number 83045809-604.01.02 at 07/07/2020.

\section{RESULTS}

Median age of the 9 patients: $32 \pm 4.66$ years (between 26-40 years), median body mass index (BMI): $24.6 \pm 1.15$. In 5 patients (55\%), BMI was over 25. Every patient except 1 had a history of cesarean section history. One patient was operated because of recurrence 3 years after their first operation in another center

All of the patients consulted with pain during their menstruation period. Six (66\%) patients presented with abdominal distension. The start of the complaints was 4.1 years following C-section. The placement of the lesions was on the left side of the incision in 5 patients (55\%), in the center in 2 patients and on the right side in 1 patient. In a patient without a history of surgical operation, the lesion was located on the right suprapubic region.

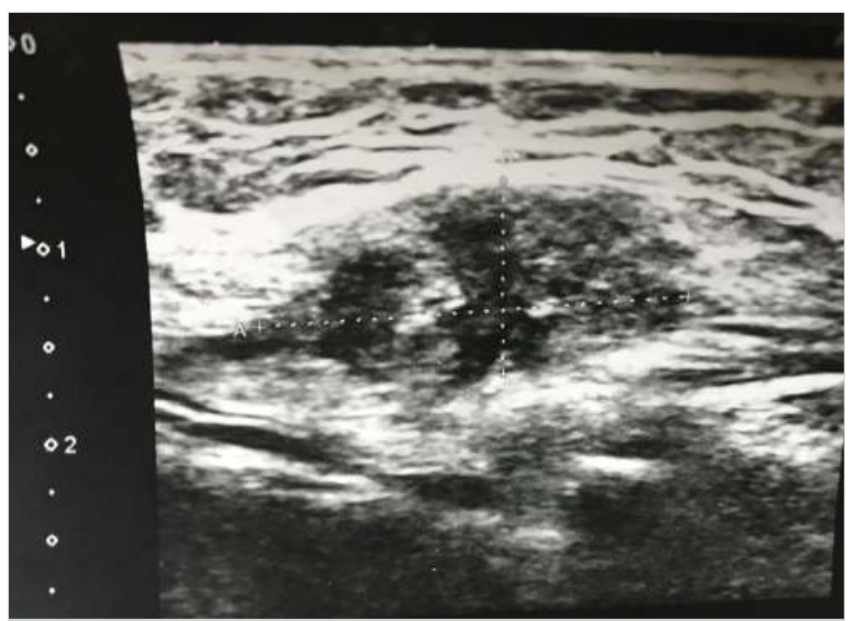

Figure 1.22×10 mm heterogeneous hypoechoic solid lesion deeply located in the anterior abdominal wall on the US.
In imaging, abdominal + superficial ultrasound (US) was used for each patient (Figure 1) Additionally, 3 patients underwent computerized tomography (CT) and 1 patient underwent abdominal magnetic resonance imaging (MRI).

For treatment, they all received en-bloc mass excision and their pathological diagnosis were compliant with endometriosis (Figure 2). Average surgery time was 40 minutes, and average endometriosis lesion dimension was $3.4 \mathrm{~cm}$. It was observed that the lesion extended to the anterior abdominal fascia in 6 of the patients, and 2 patients underwent fascia repair with propylene mesh because of the excessive defect size. Length of hospital stay was 1 day for all patients, no postoperative complications were observed in any patient. All of the patients relieved from symptoms, and no recurrence was observed during the average follow-up of period of 2.3 years.

The determined demographic and clinical data of the patients are shown in Table 1.

\section{DISCUSSION}

The presence of ectopic endometrium tissue between the subcutaneous adipose tissue and muscles in the abdominal wall is defined as abdominal wall endometriosis, and its prevalence in the general population is between $0.03 \%$ and $1 \%(5,6)$. Even though the patients are mostly of reproductive age and with a cesarean section history, cases with abdominal hysterectomy, appendectomy, laparoscopic trocar insertion sites and amniocentesis needle insertion sites have also been reported in AWE-related publications $(5,7)$. In our patients, as stated in the literature, 8 of them had one or more cesarean section history, only 1 patient had no surgical operation history similar to the very rarely observed literature cases reported as a case report.

In patients undergoing surgery, endometriosis is thought to occur through a direct implantation mechanism as a result of insufficient closure of the uterine incision or abdominal wall layers (8).

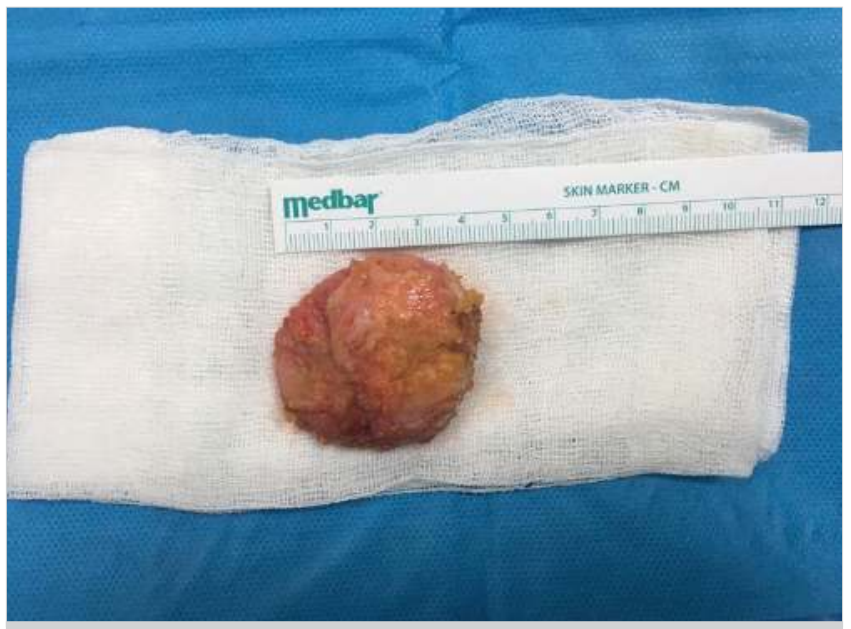

Figure 2. The view of the endometriosis resection piece. 
Table 1. Patients's demographic data and study parameters

\begin{tabular}{|c|c|c|c|c|}
\hline & $\mathrm{N}$ & $\%$ & Mean & SD \\
\hline Patients (n) & 9 & & & \\
\hline Age & & & 32 & 4.66 \\
\hline Body Mass Index $\left(\mathrm{kg} / \mathrm{m}^{2}\right)$ & & & 24.6 & 1.15 \\
\hline$<25$ & 4 & $(44.4)$ & & \\
\hline$>25$ & 5 & $(55.5)$ & & \\
\hline $\begin{array}{l}\text { Presenting symptoms } \\
\text { Cyclic abdominal pain } \\
\text { Mass palpation }\end{array}$ & $\begin{array}{l}9 \\
6\end{array}$ & $\begin{array}{l}(100) \\
(66.6)\end{array}$ & & \\
\hline $\begin{array}{l}\text { Diagnostic tests } \\
\text { Ultrasound (US) } \\
\text { Computed Tomography } \\
\text { Magnetic resonance imaging }\end{array}$ & $\begin{array}{l}9 \\
3 \\
1\end{array}$ & $\begin{array}{l}(100) \\
(33.3) \\
(11.1)\end{array}$ & & \\
\hline $\begin{array}{l}\text { Treatment } \\
\text { Surgical resection } \\
\text { Fascia involvement } \\
\text { Mesh repair }\end{array}$ & $\begin{array}{l}9 \\
6 \\
2\end{array}$ & $\begin{array}{l}(100) \\
(66.6) \\
(22.2)\end{array}$ & & \\
\hline Nodule size $(\mathrm{cm})$ & & & 3.4 & \\
\hline Hospital stay (day) & & & 1 & \\
\hline Duration of follow up (year) & & & 2.3 & \\
\hline
\end{tabular}

Similar to our 28-year-old nulliparous patient, it is considered that primitive pluripotent mesenchymal cells underwent specialized differentiation and caused endometriosis in patients without a history of surgery. It has also been reported that endometriosis may occur through lymphatic or hematogenous spread or coelomic metaplasia and changes in cellular immunity (9).

In order to prevent AWE formation through direct implantation, some techniques are recommended during surgical procedure, especially during cesarean section. These are: preventing the contact of the gases and pads that are used to clean the uterine cavity with the incision area, not comprising the endometrium during the uterine suture, washing abdominopelvic cavity, closing the visceral and parietal peritoneum, and not using the same needles for closing the uterus and abdomen $(1,10)$.

Khan et al. have shown that women with high BMI were more likely to have AWE in comparison to the control group and determined that the reason for this could be not making an appropriate closure of the uterus and abdominal wall in obese patients (8). In our series, 5 patients (55\%) presented with a BMI value above 25 in parallel with the publications.

AWE patients spend a long time from the onset of pain to the time of diagnosis and consult to many physicians. They may undergo extra examination during differential diagnosis with incisional or inguinal hernia, lipoma, cyst or soft tissue tumor. All of our patients underwent US, and 3 patients underwent a
CT scan and 1 patient underwent an MRI. US is sufficient for the diagnosis of AWE, and the solid hypoechoic appearance including vascular structures is diagnostic in the concomitantly realized Doppler US. Although CT or MRI is not an additional view for diagnosis, they are more useful in evaluating the extent and margins of the lesion $(2,11)$.

Yan Ding et al. have stated that $77 \%$ of the AWE is located on the side of the incision and that it is due to the fact that the endometrial cells are less cleaned on the incision edges (12). In our study, it was also observed that 6 (5 left, 1 right) (75\%) of the 8 patients presented with incision had the lesion located on the side.

Fine needle aspiration (FNA) accompanied by ultrasound is an effective, inexpensive method that can be used to distinguish benign and malignant during the pre-operative period. In the sample taken with FNA, endometrial-like epithelial cells, stromal cells, and hemosiderin-laden macrophages can be observed. However, the proper diagnosis may not be made for endometriosis that includes fibrosis existing for many years and insufficient sampling. Because of this situation and the risk of creating new implants at FNA entry sites, it is not a preferred method $(5,13)$. Our cases did not include patients with FNA diagnosis.

Even though medical treatments with anti-inflammatory agents, oral contraceptives containing progesterone, anti-estrogens such as danazol and gonodotropic analogs such as leuprolide acetate are tried in the treatment of AWE, their success has been 
very low and as lesion dimension did not decrease many patients underwent surgical treatment $(2,4)$. Our patients did not have any medical treatment history.

Surgical wide excision is the standard method in AWE treatment and it confirms the diagnosis. Although the intact surgical margin is stated as $1 \mathrm{~cm}$ in most publications, there is not a study showing the relationship between the surgical margin and the recurrence $(1,5,14)$. In cases including deeply located fascia, aponeurosis, muscle or peritoneum extension, if the fascia defect is bigger than 3-4 cm following the large resection the insertion of a mesh may be required (14). In our study, all patients underwent wide excision and extension to the fascia was observed in 6 patients, and propylene mesh was used to close the fascia in 2 (22\%) patients.

Malignancy development of AWE is very rare and is observed in $1 \%$ of the published cases. In publications, older age, postmenopausal period, and tumor diameter greater than $9 \mathrm{~cm}$ has been reported as a risk factor for malignancy, and conversion to tumors such as carcinosarcoma, cystadenocarcinoma, and serous papillary carcinoma has been rarely reported $(5,15)$. No malignancy diagnosis or suspicion was found in the pathology diagnoses of our study. We can state that this is related to the patient age being young (average: 32 ) and lesion dimension being small (average: $3.4 \mathrm{~cm}$ ).

The limitations of our study are the retrospective design of the stuyd and having a low number of cases, on the other hand, it is significant for us to acquire a rare case serial even though we are not a large center.

\section{CONCLUSION}

In conclusion, AWE diagnosis and treatment is a situation that takes a long time and that is rarely observed. In patients with periodic abdominal pain and swelling on the abdominal wall, AWE could be suspected and early diagnosis can be realized by carefully taking a medical history and following a physical examination, and appropriate radiological examinations and the necessary surgical intervention can be performed. The removal of the lesion through a wide excision is necessary for diagnosis and treatment, and the most significant point during manipulation is to make sure that endometriosis does not spread to the surrounding area.

Ethics Committee Approval: The ethical approval for this study was obtained from Cerrahpasa School of Medicine Clinical Research Ethical Committee (Decision no: 83045809-604-01.02- Date: 29.05.2020).

Peer-review: Externally peer-reviewed.

Author Contributions: Concept - S.E..; Design - S.E., K.K.Ö.; Supervision S.E., K.K.Ö.; Materials - S.E., K.K.Ö.; Data Collection and/or Processing - S.E., K.K.Ö.; Analysis and Interpretation - S.E., K.K.Ö.; Literature Review - S.E., K.K.Ö.; Writing Manuscript - S.E.; Critical Reviews - S.E.
Conflict of Interest: The authors declare that they have no conflict of interest.

Financial Disclosure: The authors declared that this study has received no financial support.

\section{REFERENCES}

1. Marras S, Pluchino N, Petignat P, Wenger JM, Ris F, Buchs NC, et al. Abdominal wall endometriosis: An 11-year retrospective observational cohort study. Eur J Obstet Gynecol Reprod Biol 2019; 4: 100096. [CrossRef]

2. Saliba C, Jaafoury H, El Hajj M, Nicolas G, Ahmad HH. abdominal wall endometriosis: a case report. Cureus 2019; 11-2. [CrossRef]

3. Karapolat B, Kucuk H. A rare cause of abdominal pain: scar endometriosis. Emerg Med Int 2019; 17:2584652. [CrossRef]

4. VagholkarK, Vagholkar S. Abdominal wall endometrioma: a diagnostic enigma-a case report and review of the literature. Case Rep Obstet Gynecol 2019; 2019: 6831545. [CrossRef]

5. Grigore M, Socolov D, Pavaleanu I, Scripcariu I, Grigore AM, Micu R. Abdominal wall endometriosis: an update in clinical, imagistic features, and management options. Med Ultrasound 2017; 19(4): 430-7. [CrossRef]

6. Zhang $P$, Sun $Y$, Zhang $C$, Yang $Y$, Zhang L, Wang $N$, et al. Cesarean scar endometriosis: presentation of 198 cases and literature review. BMC Women's Health 2019; 19(1): 14. [CrossRef]

7. Kaunitz A, Di Sant'Agnese PA. Needle tract endometriosis: an unusual complication of amniocentesis. Obst Gynecol 1979; 54(6): 753-5. [CrossRef]

8. Khan Z, Zanfagnin V, El-Nashar SA, Famuyide AO, Daftary GS, Hopkins MR. Risk factors, clinical presentation, and outcomes for abdominal wall endometriosis. JMIG 2017; 24(3): 478-4. [CrossRef]

9. Chang Y, Tsai EM, Long CY, Chen YH, Kay N. Abdominal wall endometriomas. J Rep Med 2009; 54(3): 155-9. [CrossRef]

10. Sumathy S, Mangalakanthi J, Purushothaman K, Sharma D, Remadevi C, Sreedhar S. Symptomatology and surgical perspective of scar endometriosis: a case series of 16 women. J Obst Gyn India 2017; 67(3): 218-23. [CrossRef]

11. Akbulut S, Mahsuni Sevinc M, Bakir S, Cakabay B, Sezgin A. Scar endometriosis in the abdominal wall: a predictable condition for experienced surgeons. Acta Chirurgica Belgica 2010; 110(3): 303-7. [CrossRef]

12. Ding Y, Zhu J. A retrospective review of abdominal wall endometriosis in Shanghai, China. Int J Gynecol Obst 2013; 121(1): 41-4. [CrossRef]

13. Gupta RK. Fine-needle aspiration cytodiagnosis of endometriosis in cesarean section scar and rectus sheath mass lesions-A study of seven cases. Diagn Cytopathol 2008; 36(4): 224-6. [CrossRef]

14. Vaz-de-Macedo C, Gomes-da-Costa A, Mendes S, Barata S, Alho C, Jorge CC, et al. abdominal wall endometriosis excision with mesh closure-report of two cases. Surg Tec Int 2016; 28: 196-201. [CrossRef]

15. Sergent F, Baron M, Le Cornec JB, Scotté M, Mace P, Marpeau L. Malignant transformation of abdominal wall endometriosis: a new case report. J Gynecol Obst Biol Rep 2006; 35(2): 186-90. [CrossRef] 
ORIJINAL ÇALIŞMA/OLGU SERISI-ÖZET

Turk J Surg 2021; 37 (1): 68-72

\title{
Karın ağrısının nadir bir nedeni: Karın duvarı endometriozisi
}

\author{
Sefa Ergün ${ }^{1}$, Kazım Koray Öner ${ }^{2}$ \\ ${ }^{1}$ Istanbul Üniversitesi-Cerrahpaşa, Cerrahpaşa Tıp Fakültesi, Genel Cerrahi Anabilim Dalı, İstanbul, Türkiye \\ ${ }^{2}$ Avcılar Murat Kölük Devlet Hastanesi, Genel Cerrahi Kliniği, İstanbul, Türkiye
}

\section{ÖZET}

Giriş ve Amaç: Endometriozis, uterusun dışında başka bir yerde uterus mukozasının bulunmasıdır. En sık pelvis yerleşimli olsa da; nadiren gastrointestinal sistem, akciğer, karaciğer, böbrek, santral sinir sistemi ve karın duvarında da görülmektedir. Karın duvarı endometriozisi (KDE) en sık, geçirilmiş sezeryan veya pelvik cerrahi sonrası oluşmaktadır. Hastalar çoğunlukla siklik karın ağrısı ve karında ele gelen kitle şikayeti ile hekime başvurmaktadır. KDE tanısında anamnez ve fizik muayene temel yöntem olup, ultrason, bilgisayarlı tomografi ve bazen batın manyetik rezonans görüntüleme kullanılmaktadır.

Gereç ve Yöntem: Çalışmamızda Avcılar Devlet Hastanesi Genel Cerrahi Servisinde Ocak 2015 ve Aralık 2018 arasında KDE ön tanısı ile ameliyat edilip patoloji sonuçları ile konfirme edilen 9 hastayı retrospektif olarak inceledik.

Bulgular: Hastaların ortalama yaşı: 32, ortalama vücut kütle endeksi: 24,6 idi. 1 hasta hariç diğer tüm hastaların en az bir kez sezeryan öyküsü vardı. 1 hasta nüks nedenli ameliyat edildi. Hastalar menstruasyon döneminde olan ağrı ve karında şişlik şikayeti ile başvurdu. Şikayetlerin başlama süresi ortalama sezeryandan 4,1 yıl sonra idi. Görüntülemede çoğunlukla ultrason kullanılmıştı. Tedavi olarak tüm hastalara kütle eksizyonu yapıldı; patolojik tanıları endometriozis ile uyumlu idi. Ortalama operasyon zamanı 40 dakika olup endometriozis lezyon boyutu ortalama $3,4 \mathrm{~cm}$ idi. Hastaların altıınnda lezyonun batın ön duvar fasyasına uzanım gösterdiği görüldü, 2 hastaya defekt büyüklüğü fazla olduğu için prolen meş ile fasya tamir işlemi yapıldı. Hiç bir hastada post-operatif komplikasyon izlenmedi, takiplerinde nüks görülmedi.

Sonuç: Dönemsel karın ağrısı ve karın duvarında şişlik olan hastalarda KDE den şüphelenilip, dikkatli bir anamnez ve fizik muayene ve uygun radyolojik tetkikler ile erken tanı konulup gerekli cerrahi müdahale yapılabilir. Tanı ve tedavisinde yöntem lezyonun geniş eksizyonla çıkarılmasıdır.

Anahtar Kelimeler: Endometriozis, karın duvarı, karın ağrısı

Doi: $10.47717 /$ turkjsurg.2021.4994 